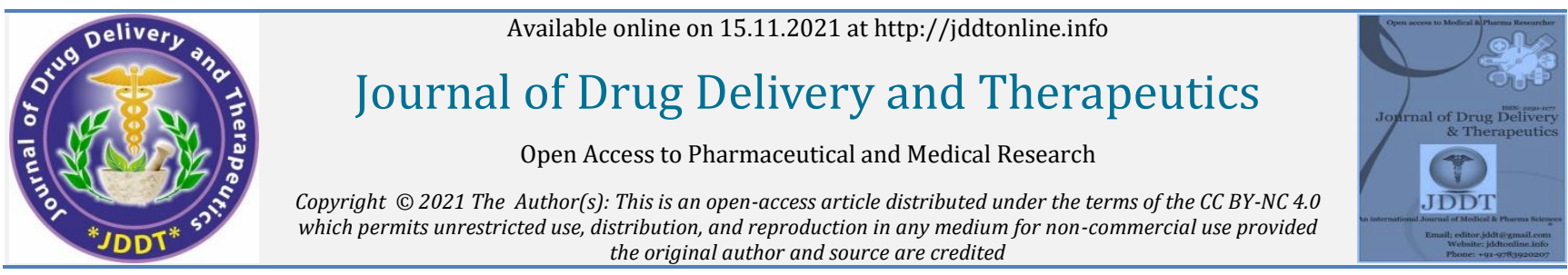

Open Access Full Text Article

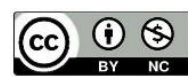

Research Article

\title{
Acute and subacute toxicity assessment of an aqueous extract of Crotalaria retusa (Fabaceae) in Swiss mice and Wistar rats
}

\author{
Lane Adrien GOH BI, Noel Kouame TOTO, Stanislas Ouga ZAHOUI, Yomalan KASSI, Semi Anthelme NENE BI*(i), \\ Flavien TRAORE
}

Laboratory of Biology and Health, Training and Research Unit Biosciences, Felix Houphouet-Boigny University (Côte d'Ivoire), 22 BP 582 Abidjan 22

Article Info:

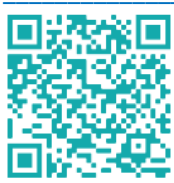

\section{Article History:}

Received 11 August 2021

Reviewed 30 September 2021

Accepted 13 October 2021

Published 15 November 2021

Cite this article as:

Goh BI LA, Toto NK, Zahoui So, Kassi Y, Nene BI SA, Traore F, Acute and subacute toxicity assessment of an aqueous extract of Crotalaria retusa (Fabaceae) in Swiss mice and Wistar rats, Journal of Drug Delivery and Therapeutics. 2021; 11(6):99-100

DOI: http://dx.doi.org/10.22270/jddt.v11i6.5080

\author{
Abstract
}

The present study is a contribution to the enhancement of Ivorian traditional medicine, by carrying out bio-tolerance tests of an aqueous extract of the aerial parts of Crotalaria retusa (EACr) in mice and rats according to the guidelines of the Organization for Economic Co-operation and Development (OECD) 423 and 407, respectively. The doses of 2000 and $5000 \mathrm{mg} / \mathrm{kg}$ of body weight (BW) of the extract were used for acute toxicity. For subacute toxicity which lasted 28 days, doses of 500,1000 , and $2000 \mathrm{mg} / \mathrm{kg}$ BW have been used. The administration of the single doses of 2000 and $5000 \mathrm{mg} / \mathrm{kg} \mathrm{BW}$ of EACr did not provoke death in female mice in the acute toxicity setting. For subacute toxicity in rats (male and female), the administration of repetitive doses of 500, 1000, and $2000 \mathrm{mg} / \mathrm{kg} \mathrm{BW}$ of EACr over a period of 28 days did not cause death in these animals. In females, these doses caused weight loss and a decrease in platelets. The extract reduced the activity of AST in both sexes of rats. The findings also showed that this extract would possess a nephroprotective property in male and female rats.

Keywords: Crotalaria retusa, Acute and subacute toxicities, Wistar rat, Swiss mice

*Address for Correspondence:

Semi Anthelme NENE BI, Laboratory of Biology and Health, Training and Research Unit Biosciences, Felix Houphouet-Boigny University (Côte d'Ivoire), 22 BP 582 Abidjan 22 ORCIS ID: https://orcid.org/0000-0003-3162-2075

\section{INTRODUCTION}

In 2011, at its 66th General Assembly, the UN classified metabolic diseases as a new challenge in the fight for the improvement of public health ${ }^{1}$. Among these pathologies, diabetes occupies a preponderant place. It is an endocrine disease characterized by chronic hyperglycemia due to a defect in insulin secretion (type I diabetes) or its action (type II diabetes) or both ${ }^{2}$. According to the International Diabetes Federation (IDF), the prevalence of diabetes increased from $5.7 \%$ before 2000 to $9.6 \%$ in 2010 in Cote $\mathrm{d}^{\prime}$ Ivoire ${ }^{3}$. The district of Abidjan (Cote d'Ivoire), because of its urbanization, is the region most affected by diabetes 4 . The management of diabetics is very expensive, by regularly taking blood sugar levels and adjusting them by injecting insulin. Thus, populations in developing countries are turning to traditional medicine for the treatment of this disease ${ }^{5}$.

Plants used to treat diabetes occupy an important place in the lives of populations given its rate of death around the world. The West African flora, and particularly that of the Cote d'Ivoire, abound several species of plants that have real anti-diabetic properties, but which have not been yet the subject of in-depth scientific studies. This is the case of Crotalaria retusa L (Fabaceae), a plant whose leaves and flowers are used in the treatment of fever and lung diseases in Burkina Faso ${ }^{6}$. The powder of its seeds is indicated in leprosy, flatulence and acts as an analgesic against the pain of scorpion stings and snake venom ${ }^{7}$.

According to Talalay ${ }^{8}$, it is important that all herbal medicines are tested for safety (toxicity) before studying their effectiveness. The objective of this work is to assess the acute and subacute toxicities of an aqueous extract of Crotalaria retusa L (Fabaceae), respectively in mice and rats.

\section{MATERIAL AND METHODS}

\section{Plant material}

The plant material consists of leaves, flowers, and seeds of Crotalaria retusa (Fabaceae). It was harvested in Bianouan, a locality located in southern Comoe on the AboissoAbengourou axis, 200 kilometers from Abidjan (Cote d'Ivoire). The authentication was made by Professor Zirihi Guede Noel thanks to herbaria numbers 15133 of 22-021980, 51 of 1502-1991, 4258 of 18-11-1974, and 11022 of 06-01-1970 of the National Floristic Center (NFC) in Abidjan (Cote d'Ivoire).

Preparation of the aqueous extract of Crotalaria retusa $L$ (Fabaceae)

The leaves, seeds, and flowers are dried at room temperature $\left(25^{\circ} \mathrm{C}\right)$ in the shade and crushed in a mechanical grinder. Fifty grams $(50 \mathrm{~g})$ of ground material are mixed with slow magnetic stirring for 24 hours in 1 liter 
of distilled water. The macerate is filtered through cotton wool, then through "Whatman No. 2" filter paper. The resulting filtrate was dried in an oven at $50^{\circ} \mathrm{C}$. A fine, perfectly water-soluble, brown powder is obtained, which is the crude aqueous extract of Crotalaria retusa (EACr). A stock solution is then prepared from this powder.

\section{Animal material}

Female mice of the species Mus musculus (Muridae), of homogeneous parental strains Swiss, weighing between 20 and $25 \mathrm{~g}$, were used for the acute toxicity tests.

Rats of the species Rattus norvegicus of the Wistar strain, weighing between 120 and $150 \mathrm{~g}$, were used for the subacute toxicity tests. All those animals come from the vivarium of the superior normal School in Abidjan (Cote d'Ivoire). They are fed with the pellet supplied by the IVOGRAIN@ company (Ivory Coast) and have free access to water. The animals were acclimatized under laboratory conditions before the start of the experiment.

\section{Acute toxicity study}

The study of acute oral toxicity is carried out on 12 female mice weighing between 20 and 25 g. This study is carried out according to the guidelines of the Organization for Economic Co-operation and Development (OECD-423) 9. The doses of 2000 and $5000 \mathrm{mg} / \mathrm{kg}$ were chosen to carry out this study. Each mouse receives $1 \mathrm{ml}$ of a single dose of the extract, evaluated as $\mathrm{mg} / \mathrm{kg}$ of body weight. The tests were carried out in 2 phases with 6 animals, at a rate of 3 mice per stage and per dose. After administration of the extract, the mice are again deprived of food for 1 to 2 hours. Animals are observed individually at least once during the first 30 minutes and every 24 hours after treatment. Special care should be taken during the first four (4) hours and daily for 14 days after administration of the extracts. Observations focus on changes in hair, eyes, and behavior.

\section{Subacute toxicity study}

The experiment was carried out according to OECD test guideline 407 (OECD-407) ${ }^{10}$. Four (4) groups of six (6) rats of both (2) sexes of the Wistar strain, with a body mass of between 120 and $150 \mathrm{~g}$ were made up and distributed as follows: group 1 constitutes the control group, in which rats received distilled water by gavage at a rate of $1 \mathrm{ml} / 100 \mathrm{~g}$ of body weight during this time; rats of test groups 2,3 , and 4 respectively received the doses of 500, 1000, and 2000 $\mathrm{mg} / \mathrm{kg} \mathrm{BW}$ of EACr every day at the same time for four weeks.

The animals were observed individually each day during the 28 days of the experiment. The rats were weighed weekly until the end of the experiment. The blood samples were taken before the administration of the extract (D0), on the fourteenth and twenty-eighth days of the tests for the assays of the biochemical and hematological parameters likely to reveal the toxicity. A dissection was also carried out for the removal and the weighing of the organs allowing the calculation of the relative weights.

\section{Statistical analysis}

Graphpad Prism 5 software (San Diego, California, USA) was used for statistical analysis and plotting of the graphs. Analysis of variance (ANOVA) followed by the NewmanKeuls multiple comparison test of means, were used to rank, and compare the means. The means are always followed by their standard deviations. Two means are different if the probability that results from the statistical tests is less than or equal to $0.05(\mathrm{p}<0.05)$. Otherwise, these differences are not significant $(\mathrm{P}>0.05)$.

\section{RESULTS}

\section{Acute toxicity}

Administration by gavage of single doses of 2000 and 5000 $\mathrm{mg} / \mathrm{kg} \mathrm{BW}$ of aqueous extract of Crotalaria retusa (EACr), causes decreased motor skills in mice and a pooling of these in a corner of the cage. This phenomenon begins 25 minutes after administration of the extract and lasts about 40 minutes to an hour. However, these doses did not cause any death in the treated mice after two weeks (14 days) of observation.

\section{Subacute toxicity}

This study was carried out over a period of 28 days on male and female rats of the Wistar strain. It evaluated the effects of doses of 500, 1000 and $2000 \mathrm{mg} / \mathrm{kg} \mathrm{BW}$ of aqueous extract of Crotalaria retusa on certain parameters in test animals.

\section{Effects of EACr on the body mass of rats}

Figure 1 shows the effects of the administration of the different doses of the aqueous extract of Crotalaria retusa on the weight of the rats. These results show a non-significant weight gain in male rats after daily treatment for 28 days (Figure 1A). However, a decrease in weight was observed in the treated female rats (Figure 1B). This weight loss is very pronounced in the rats given the dose of $500 \mathrm{mg} / \mathrm{kg}$ BW.

\section{Effects of EACr on biomarkers of liver function in rats}

The effects of the aqueous extract of Crotalaria retusa on the parameters of liver function are shown in Table I. This table shows a significant decrease in AST activity observed at a dose of $500 \mathrm{mg} / \mathrm{Kg} \mathrm{BW}$ in males and in females after 28 days of daily administration. Other than this dose, EACr did not significantly alter ALT activities and total bilirubin level in any treated batches compared to the control.

\section{Effects of EACr on biomarkers of renal function in rats}

The parameters of renal function were evaluated at doses of 500,1000 and $2000 \mathrm{mg} / \mathrm{kg} \mathrm{BW}$ in the subacute toxicity study. The results reported in Table II show that this aqueous extract of Crotalaria retusa does not significantly modify the urea, creatinine, and uric acid levels during the experimentation period.

\section{EACr Effects on Serum Electrolytes in Rats}

Table III shows the effects of EACr on serum electrolytes in male and female rats. These results show that this extract, at the doses used, does not significantly modify the blood ionogram in both sexes in the treated rat.

\section{Effects of EACr on hematological parameters in rats}

Table IV presents the results of EACr at different doses on the hematological parameters in male rats and in female rats during the experimental period. These data show that daily administration at different doses of EACr does not significantly alter hemoglobin, hematocrit, and red blood cell levels in either sex. However, the level of blood platelets undergoes a significant decrease for the dose of $500 \mathrm{mg} / \mathrm{Kg}$ BW in females, and this decrease becomes very significant for the doses of 1000 and $2000 \mathrm{mg} / \mathrm{Kg} \mathrm{BW}$ in the same sex while the level of this parameter does not vary in male rats in all the batches and for the different doses administered. As regards the white blood cells, their level undergoes a slight decrease in all the batches in the female rats and remains practically constant in the male rats at different administered doses. 


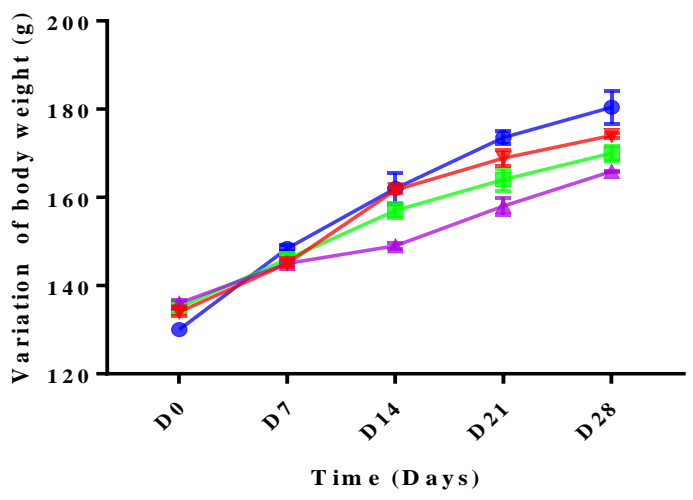

B

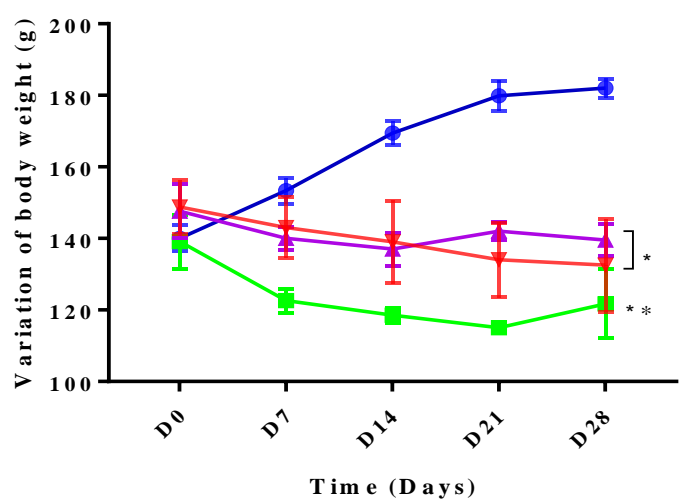

$\rightarrow$ Control

$-500 \mathrm{mg} / \mathrm{kg} \mathrm{BW}$

$\leftarrow \quad 1000 \mathrm{mg} / \mathrm{kg} \mathrm{B} \mathrm{W}$

$\rightarrow \quad 2000 \mathrm{mg} / \mathrm{kg} \mathrm{B} \mathrm{W}$

Figure 1: Effect of the aqueous extract of Crotalaria retusa on the body mass of male (A) and female (B) rats during 4 weeks of treatment. EACr significantly decreases the body mass of female rats treated at doses of 500 and $2000 \mathrm{mg} / \mathrm{kg}$ BW. Values are presented as an average $\pm \mathrm{SEM},{ }^{*} 0,05<p ;{ }^{* *} 0,01<p, n=6$.

Table I: Effects of EACr on Biomarkers of Liver Function in male and female Wistar Strain Rats

\begin{tabular}{|c|c|c|c|c|c|c|c|c|c|}
\hline \multirow[b]{3}{*}{ Lots / Doses } & \multicolumn{9}{|c|}{ Biomarkers of the hepatic function } \\
\hline & \multicolumn{3}{|c|}{ Do } & \multicolumn{3}{|c|}{ D14 } & \multicolumn{3}{|c|}{ D28 } \\
\hline & AST & ALT & TB & AST & ALT & TB & AST & ALT & TB \\
\hline \multicolumn{10}{|l|}{ Males } \\
\hline Lot 1: Distilled water & $186 \pm 0,3$ & $73 \pm 0,5$ & $5 \pm 0,3$ & $175 \pm 0,5$ & $89 \pm 0,6$ & $5 \pm 0,4$ & $205 \pm 1,4$ & $74 \pm 0,3$ & $5 \pm 0,4$ \\
\hline Lot 2: $500 \mathrm{mg} / \mathrm{Kg} \mathrm{BW}$ & $200 \pm 0,5$ & $81 \pm 0,3$ & $6 \pm 0,2$ & $150 \pm 3,9$ & $75 \pm 2,0$ & $5 \pm 0,6$ & $95 \pm 2,8^{*}$ & $74 \pm 2,9$ & $5 \pm 0,6$ \\
\hline Lot 3: $1000 \mathrm{mg} / \mathrm{Kg} \mathrm{BW}$ & $198 \pm 1,0$ & $68 \pm 0,2$ & $5 \pm 0,3$ & $190 \pm 2,3$ & $70 \pm 0,1$ & $4 \pm 0,1$ & $202 \pm 2,1$ & $69 \pm 2,13$ & $7 \pm 0,1$ \\
\hline Lot 4: $2000 \mathrm{mg} / \mathrm{Kg} \mathrm{BW}$ & $199 \pm 1,2$ & $75 \pm 0,9$ & $5 \pm 0,1$ & $195 \pm 4,3$ & $65 \pm 1,2$ & $4 \pm 0,1$ & $206 \pm 3,1$ & $63 \pm 1,02$ & $7 \pm 0,6$ \\
\hline \multicolumn{10}{|l|}{ Females } \\
\hline Lot 1: Distilled water & $200 \pm 1$ & $53 \pm 0,5$ & $5 \pm 0,3$ & $220 \pm 1$ & $64 \pm 0,6$ & $5 \pm 0,3$ & $242 \pm 2$ & $71 \pm 0,3$ & $5 \pm 0,2$ \\
\hline Lot 2: $500 \mathrm{mg} / \mathrm{Kg} \mathrm{BW}$ & $210 \pm 1$ & $56 \pm 0,3$ & $4 \pm 0,13$ & $143 \pm 2$ & $55 \pm 0,5$ & $5 \pm 0,8$ & $142 \pm 1^{*}$ & $57 \pm 2,12$ & $4 \pm 0,3$ \\
\hline Lot 3: $1000 \mathrm{mg} / \mathrm{Kg} \mathrm{BW}$ & $199 \pm 2$ & $51 \pm 0,8$ & $6 \pm 0,40$ & $193 \pm 3$ & $68 \pm 2,2$ & $4 \pm 0,3$ & $202 \pm 3$ & $59 \pm 0,02$ & $5 \pm 0,5$ \\
\hline Lot 4: $2000 \mathrm{mg} / \mathrm{Kg} \mathrm{BW}$ & $189 \pm 1$ & $50 \pm 0,5$ & $5 \pm 0,34$ & $191 \pm 2$ & $48 \pm 1,1$ & $5 \pm 0,2$ & $201 \pm 2$ & $45 \pm 2,13$ & $6 \pm 0,3$ \\
\hline
\end{tabular}

EACr at a dose of $500 \mathrm{mg} / \mathrm{kg}$ BW results in a significant decrease in AST activity in male and female rats. Values are presented as a mean \pm SEM, ${ }^{*} 0,05<p ;{ }^{* *} 0,01<p, n=6$. AST: Aspartate aminotransferase, ALT: Alanine aminotransferase, TB: Total bilirubin

D0 = Days before the administration of the extract, D14= Days 14 (Two weeks after the administration of the extract), D28= Days 28 (Four weeks after the administration of the extract) 
Table II: Effects of EACr on Biomarkers of Renal Function in male and females Rats

\begin{tabular}{|c|c|c|c|c|c|c|c|c|c|}
\hline \multirow[b]{3}{*}{ Lots/Doses } & \multicolumn{9}{|c|}{ Biomarkers of renal function } \\
\hline & \multicolumn{3}{|c|}{ D0 } & \multicolumn{3}{|c|}{ D14 } & \multicolumn{3}{|c|}{ D28 } \\
\hline & Urea & Creat & Uric acid & Urea & Creat & Uric acid & Urea & Creat & Uric acid \\
\hline \multicolumn{10}{|l|}{ Males } \\
\hline Lot 1: Distilled water & $0,4 \pm 0,1$ & $3,3 \pm 0,1$ & $24 \pm 3,0$ & $0,4 \pm 0,1$ & $4 \pm 0,3$ & $25 \pm 1,1$ & $0,4 \pm 0,01$ & $6 \pm 0,6$ & $24 \pm 1,2$ \\
\hline Lot2: $500 \mathrm{mg} / \mathrm{Kg} \mathrm{BW}$ & $0,3 \pm 0,2$ & $6 \pm 0,03$ & $27 \pm 2,1$ & $0,3 \pm 0,2$ & $5 \pm 0,6$ & $25 \pm 1,1$ & $0,2 \pm 0,01$ & $4 \pm 0,01$ & $20 \pm 1,7$ \\
\hline Lot3: $1000 \mathrm{mg} / \mathrm{Kg} \mathrm{BW}$ & $0,3 \pm 0,5$ & $5,2 \pm 0,6$ & $25 \pm 1,9$ & $0,3 \pm 0,1$ & $5 \pm 0,8$ & $20 \pm 1,2$ & $0,3 \pm 0,05$ & $4 \pm 0,3$ & $27 \pm 5,5$ \\
\hline Lot4: $2000 \mathrm{mg} / \mathrm{Kg} \mathrm{BW}$ & $0,3 \pm 0,5$ & $6 \pm 0,01$ & $26 \pm 2,0$ & $0,3 \pm 0,2$ & $5 \pm 0,6$ & $26 \pm 0,5$ & $0,3 \pm 0,05$ & $3,3 \pm 0,3$ & $30 \pm 3,4$ \\
\hline \multicolumn{10}{|l|}{ Females } \\
\hline Lot 1: Distilled water & $0,4 \pm 0,3$ & $4 \pm 0,6$ & $28 \pm 0,6$ & $0,3 \pm 0,3$ & $6 \pm 0,3$ & $26 \pm 0,3$ & $0,4 \pm 0,1$ & $7,2 \pm 0,4$ & $31 \pm 0,6$ \\
\hline Lot2: $500 \mathrm{mg} / \mathrm{Kg} \mathrm{BW}$ & $0,3 \pm 0,4$ & $5 \pm 0,3$ & $30 \pm 0,5$ & $0,3 \pm 0,1$ & $5 \pm 0,3$ & $21 \pm 1,6$ & $0,3 \pm 0,4$ & $3,3 \pm 0,3$ & $19 \pm 1,2$ \\
\hline Lot3: $1000 \mathrm{mg} / \mathrm{Kg} \mathrm{BW}$ & $0,3 \pm 0,1$ & $5 \pm 0,4$ & $26 \pm 0,4$ & $0,3 \pm 0,2$ & $3 \pm 0,1$ & $21 \pm 1,7$ & $0,2 \pm 0,1$ & $2,7 \pm 0,2$ & $21 \pm 0,6$ \\
\hline Lot4: $2000 \mathrm{mg} / \mathrm{Kg} \mathrm{BW}$ & $0,4 \pm 0,2$ & $4 \pm 0,5$ & $29 \pm 0,7$ & $0,3 \pm 0,1$ & $4 \pm 0,3$ & $18 \pm 1,2$ & $0,3 \pm 0,1$ & $3,1 \pm 1,4$ & $19 \pm 0,3$ \\
\hline
\end{tabular}

EACr did not cause significant changes in Urea, Creatinine and Uric Acid levels after 28 days of administration in male rats. Values are presented as a mean $\pm S E M, n=6$. Creat: Creatinine

D0 = Days before the administration of the extract, D14= Days 14 (Two weeks after the administration of the extract), D28= Days 28 (Four weeks after the administration of the extract)

Table III: Effects of EACr on Electrolyte Parameters in male and female rats

\begin{tabular}{|c|c|c|c|c|c|c|c|c|c|}
\hline \multirow{3}{*}{ Lots/Doses } & \multicolumn{9}{|c|}{ Electrolytic parameters } \\
\hline & \multicolumn{3}{|c|}{ D0 } & \multicolumn{3}{|c|}{ D14 } & \multicolumn{3}{|c|}{ D28 } \\
\hline & $\mathrm{Na}+$ & $\mathbf{K}+$ & Cl- & $\mathrm{Na}+$ & $\mathbf{K}+$ & $\mathrm{Cl}-$ & $\mathrm{Na}+$ & $\mathbf{K}+$ & $\mathrm{Cl}-$ \\
\hline \multicolumn{10}{|l|}{ Males } \\
\hline Lot1: Distilled water & $140 \pm 1,23$ & $5,2 \pm 0,1$ & $97 \pm 1,5$ & $141 \pm 1,5$ & $5 \pm 0,5$ & $7 \pm 0,3$ & $139 \pm 0,6$ & $4 \pm 1,5$ & $101 \pm 1,4$ \\
\hline Lot2: 500 mg/Kg BW & $139 \pm 1,11$ & $5,3 \pm 0,8$ & $98 \pm 1,5$ & $147 \pm 1,7$ & $6 \pm 0,4$ & $96 \pm 1,2$ & $140 \pm 3,2$ & $5 \pm 0,4$ & $98 \pm 2,9$ \\
\hline Lot3:1000 mg/Kg BW & $142 \pm 1,7$ & $7 \pm 0,9$ & $97 \pm 1,3$ & $144 \pm 1,1$ & $4 \pm 0,1$ & $9 \pm 0,5$ & $143 \pm 0,5$ & $4 \pm 0,2$ & $104 \pm 3,5$ \\
\hline Lot $4: 2000 \mathrm{mg} / \mathrm{Kg} \mathrm{BW}$ & $138 \pm 4,7$ & $8 \pm 1,4$ & $98 \pm 1,4$ & $142 \pm 0,6$ & $5 \pm 0,3$ & $9 \pm 1,1$ & $143 \pm 2,0$ & $5 \pm 0,3$ & $100 \pm 0,6$ \\
\hline \multicolumn{10}{|l|}{ Females } \\
\hline Lot1: Distilled water & $137 \pm 1,4$ & $5,5 \pm 0,1$ & $98 \pm 1,5$ & $139 \pm 1,3$ & $5 \pm 0,5$ & $97 \pm 0,3$ & $138 \pm 0,6$ & $4 \pm 1,5$ & $99 \pm 1,4$ \\
\hline Lot2: 500 mg/Kg BW & $139 \pm 1,2$ & $5,2 \pm 0,2$ & $97 \pm 1,5$ & $145 \pm 0,6$ & $6 \pm 0,2$ & $98 \pm 0,5$ & $143 \pm 0,3$ & $5 \pm 0,7$ & $103 \pm 0,5$ \\
\hline Lot3:1000 mg/Kg BW & $141 \pm 1,1$ & $4,8 \pm 0,3$ & $100 \pm 1,5$ & $143 \pm 2,6$ & $5 \pm 0,3$ & $99 \pm 2,6$ & $142 \pm 0,8$ & $5 \pm 0,2$ & $105 \pm 1,4$ \\
\hline Lot4:2000 mg/Kg BW & $138 \pm 1,7$ & $7 \pm 0,12$ & $97 \pm 1,3$ & $144 \pm 0,5$ & $4 \pm 0,6$ & $97 \pm 0,5$ & $141 \pm 0,5$ & $5 \pm 0,1$ & $101 \pm 0,1$ \\
\hline
\end{tabular}

EACr does not cause a significant change in the serum ionogram after 28 days of daily administration in male and female rats. Values are presented as a mean $\pm S E M, n=6$.

D0 = Days before the administration of the extract, D14= Days 14 (Two weeks after the administration of the extract), D28= Days 28 (Four weeks after the administration of the extract) 
Table IV: Effects of EACr on hematological biomarkers in male and female rats

\begin{tabular}{|c|c|c|c|c|c|c|c|c|c|c|}
\hline \multirow[b]{3}{*}{ Lots/ Doses } & \multicolumn{10}{|c|}{ Blood parameters } \\
\hline & \multicolumn{5}{|c|}{ D0 } & \multicolumn{5}{|c|}{ D28 } \\
\hline & WBC & RBC & HCT & PLT & Hgb & WBC & RBC & HCT & PLT & Hgb \\
\hline \multicolumn{11}{|l|}{ Males } \\
\hline Lot1: Distilled water & $16 \pm 1,1$ & $8 \pm 1$ & $40 \pm 2$ & $841 \pm 1$ & $14 \pm 0,2$ & $15 \pm 1,0$ & $8 \pm 1,4$ & $39 \pm 1,6$ & $834 \pm 1$ & $14 \pm 1,1$ \\
\hline Lot2: 500 mg/Kg BW & $15 \pm 0,5$ & $9 \pm 1$ & $37 \pm 1,3$ & $698 \pm 2$ & $13 \pm 0,2$ & $12 \pm 0,6$ & $6 \pm 0,3$ & $39 \pm 0,8$ & 735,3 & $14 \pm 0,2$ \\
\hline Lot3:1000 mg/Kg BW & $16 \pm 1,2$ & $9 \pm 2$ & $41 \pm 1,6$ & $723 \pm 1$ & $14 \pm 0,6$ & $13 \pm 1,0$ & $7 \pm 0,4$ & $40 \pm 2,3$ & $805 \pm 2$ & $14 \pm 0,9$ \\
\hline Lot4:2000 mg/Kg BW & $17 \pm 1,8$ & $11 \pm 2$ & $39 \pm 2$ & $669 \pm 2$ & $15 \pm 0,3$ & $10 \pm 1,5$ & $7 \pm 0,2$ & $38 \pm 0,3$ & $566 \pm 1$ & $14 \pm 0,1$ \\
\hline \multicolumn{11}{|l|}{ Females } \\
\hline Lot1: Distilled water & $14 \pm 1,5$ & $7 \pm 1$ & $36 \pm 1,4$ & $698 \pm 3$ & $14 \pm 1,3$ & $13 \pm 0,1$ & $4 \pm 0,3$ & $39 \pm 2,3$ & $804 \pm 2$ & $13 \pm 0,3$ \\
\hline Lot2: 500 mg/Kg BW & $13 \pm 0,4$ & $8 \pm 0,3$ & $34 \pm 0,3$ & $938 \pm 2$ & $12 \pm 0,9$ & $12 \pm 0,5$ & $7 \pm 0,3$ & $39 \pm 0,4$ & $626 \pm 1 *$ & $12 \pm 0,1$ \\
\hline Lot3: 1000 mg/Kg BW & $15 \pm 1,9$ & $8 \pm 0,7$ & $37 \pm 0,5$ & $807 \pm 2$ & $13 \pm 1,1$ & $13 \pm 0,4$ & $6 \pm 0,2$ & $33 \pm 0,3$ & $432 \pm 1^{* *}$ & $13 \pm 0,3$ \\
\hline Lot4: 2000 mg/Kg BW & $12 \pm 0,7$ & $6 \pm 0,5$ & $34 \pm 0,4$ & $949 \pm 3$ & $13 \pm 0,6$ & $14 \pm 0,1$ & $6 \pm 0,3$ & $31 \pm 1,8$ & $262 \pm 1 * *$ & $12 \pm 0,6$ \\
\hline
\end{tabular}

\section{Effects of EACr on the relative organ mass of rats}

Table V shows the effect of EACr on relative organ weights in male and female rats. These results show that during the 28 days of treatment, the different doses administered to the animals practically do not modify the weight of their organs compared with the control groups, whatever the sex.

Table V: Effect of EACr on the Relative Organ Mass of male and female rats

\begin{tabular}{|c|c|c|c|c|c|}
\hline \multirow[b]{2}{*}{ Organs } & \multirow[t]{2}{*}{ Live weight } & \multicolumn{3}{|c|}{ Relative weights } & \multirow[b]{2}{*}{ Spleen } \\
\hline & & Heart & Liver & Kidney & \\
\hline \multicolumn{6}{|l|}{ Males } \\
\hline Lot1: Distilled water & $123 \pm 1,03$ & $0,40 \pm 0,02$ & $3,74 \pm 0,23$ & $0,55 \pm 0,3$ & $0,28 \pm 0,013$ \\
\hline Lot2: 500 mg /Kg BW & $133 \pm 1,73$ & $0,42 \pm 0,023$ & $4,03 \pm 0,12$ & $0,62 \pm 0,029$ & $0,29 \pm 0,015$ \\
\hline Lot3: 1000 mg/Kg BW & $122,5 \pm 1,03$ & $0,51 \pm 0,092$ & $3,64 \pm 0,104$ & $0,66 \pm 0,015$ & $0,23 \pm 0,043$ \\
\hline Lot4: 2000 mg / Kg BW & $157,5 \pm 1,44$ & $0,45 \pm 0,015$ & $3,80 \pm 0,14$ & $0,61 \pm 0,02$ & $0,28 \pm 0,02$ \\
\hline \multicolumn{6}{|l|}{ Females } \\
\hline Lot1: Distilled water & $138 \pm 0,9$ & $0,45 \pm 0,1$ & $3,54 \pm 0,15$ & $0,53 \pm 0,02$ & $0,33 \pm 0,016$ \\
\hline Lot2: 500 mg/ Kg BW & $131 \pm 1,04$ & $0,61 \pm 0,104$ & $3,75 \pm 0,28$ & $0,65 \pm 0,006$ & $0,3 \pm 0,04$ \\
\hline Lot3:1000 mg/ Kg BW & $139 \pm 1,08$ & $0,55 \pm 0,028$ & $4,03 \pm 0,13$ & $0,67 \pm 0,03$ & $0,34 \pm 0,008$ \\
\hline Lot4 :2000 mg/ Kg BW & $132 \pm 0,34$ & $0,46 \pm 0,023$ & $3,6 \pm 0,06$ & $0,59 \pm 0,026$ & $0,31 \pm 0,017$ \\
\hline
\end{tabular}




\section{DISCUSSION}

Acute oral toxicity testing at doses of 2000 and $5000 \mathrm{mg} / \mathrm{kg}$ BW of aqueous extract of Crotalaria retusa did not result in any deaths during the study period in treated mice. This shows that EACr at a lethal dose $50 \%$ greater than 5000 $\mathrm{mg} / \mathrm{kg}$ BW. This extract therefore has a toxicity index equivalent to 5 , according to the toxicity scale of a chemical substance depending on the LD50 and the route of administration 11 . The absence of toxicity by gavage observed with the aqueous extract of Crotalaria retusa has been demonstrated by some authors working with the aqueous extracts of plants of the traditional African pharmacopoeia such as Parkia biglobosa (Mimosaceae) and Annona senegalensis (Annonaceae) and Hallea ledemannii (Rubiaceae) 12,13.

Due to the absence of toxic effects during the acute toxicity study, an additional study was conducted to assess the subacute toxicity of EACr over a period of 28 days in rats. In this study, weight loss in female rats compared to the control group was observed after daily treatment for 28 days. The weight loss observed in females may presage that EACr causes loss of appetite promoting weight loss due to disturbances in the metabolism of carbohydrates, proteins, or fats. These results agree with those of Guirou ${ }^{14}$, in fact, this author has shown that the aqueous extract of Argemone mexicana lowers body weight in female rats and has no effect in males. Furthermore, no significant changes were observed in the weight of organs such as the heart, liver, spleen, and kidneys, suggesting that daily administration of the aqueous extract of Crotalaria retusa had no effect on their normal growth. Relative organ weight is a relatively sensitive indicator in toxicity studies 15 . The role of hepatocytes is to neutralize toxins, whether they come from inside or outside the body (detoxification), while the kidney's role is to purify the blood and eliminate waste 16 . Analysis of liver and kidney function is therefore very important in assessing the toxicity of drugs and plant extracts as they are necessary for the survival of an organism ${ }^{17}$. The biochemical analysis performed showed a significant decrease in the level of AST in both sexes. Other than this dose, all the doses used did not significantly change the level of AST, ALT and total bilirubin compared to the control group. Similar results were obtained by Mukinda and Syce 18 with aqueous extract of Aztemisia afra in rats. These enzymes increase in myopathy, myocardial infarction, and AST, especially in hemolysis. ALTs are more specific for liver damage, but ASTs are somewhat more sensitive ${ }^{19}$. In the case of this study, the results show that the aqueous extract of Crotalaria retusa may have hepato-protective action. Renal examination revealed that administration of the extract did not produce any significant changes in urea, serum creatinine and uric acid levels. Serum urea and creatinine are the main markers of nephrotoxicity, although serum urea is often considered a more reliable predictor of renal function than serum creatinine 20 . Like those of Alain et al. 21 and can predict that EACr is a good nephroprotective effect. The analysis of blood parameters is relevant because it gives information on the hematopoietic function, on the appearance of allergies and on intravascular effects such as hemolysis. The hematologic workup showed a drop in blood platelets in female rats, which would make this extract an anticoagulant. Blood platelets help the blood to clot by stopping the bleeding. Moreover, EACr at different doses does not significantly modify the electrolytes after four weeks of gavage. These results are like those of Omigie and Agoreyo who showed that the aqueous extract of Citrullus lanatus (Cucurbitaceae) seeds did not modify the content of electrolyte parameters and blood parameters ${ }^{22}$.

\section{CONCLUSION}

This study showed that the $50 \%$ lethal dose of the aqueous extract of Crotalaria retusa would be above $5000 \mathrm{mg} / \mathrm{kg} \mathrm{BW}$ in mice. For repeated oral administration to rats, this substance caused a decrease in body weight and platelets in females, in addition, to provoke a decrease AST activity after 28 days in both sexes. The results obtained also showed that Crotalaria retusa aqueous extract would possess a nephroprotective property in male and female rats. All the data are in favor of traditional use of the aqueous extract of this plant at a therapeutic dose for a short and long term, in the care of patients.

\section{Acknowledgments}

The authors are grateful to Professor Zirihi Guede Noel, Felix Houphouet-Boigny university, Côte d'Ivoire for providing plant material.

\section{Conflicts of Interest}

The Authors declare that there is no conflict of interest.

\section{REFERENCES}

1. Alwan A, Maclean DR, Riley LM, d'Espaignet ET, Mathers CD, Stevens GA, Bettcher D, Monitoring and surveillance of chronic on- communicable diseases: progress and capacity in highburden countries. Lancet. 2010; 376(9755):1861-1868. doi:https://DOI.org/10.1016/S0140-6736(10)61853-3. https://doi.org/10.1016/S0140-6736(10)61853-3

2. N'Diaye M, Diatta W, Sy GY, Fall AD, Faye B, Bassene E, Activité anti hyperglycémiante de l'extrait éthanolique de feuilles de Icacina senegalensis juss (Icacinaceae). MAN. 2008; 55:441-445.

3. Fédération Internationale du Diabète, Réponse de la FID à la consultation de l'OMS portant sur le Plan d'action mondial 2013-2020 pour la prévention et le contrôle des MNT. Brusselles: FID, 2013, p. 72.

4. Gbakayoro JB, Etude de comportements alimentaires et de leurs implications dans l'apparition du diabète sucré en Côte d'Ivoire, chez les populations baoulé, malinké et agni Thèse 3ème Cycle, Université Nangui Abrogoua, Côte d'Ivoire, 2016, p. 103.

5. Matheka DM, Demaio AR, 2013 Complementary and alternative medicine use among diabetic patients in Africa: Kenyan perspective. PanAfrMedJ. $15: 110$. DOI:10.11604/pamj.2013.15.110.2925. https://doi.org/10.11604/pamj.2013.15.110.2925

6. Wiedenfeld $\mathrm{H}$, Plantes contenant de la pyrrolizidine alcaloïdestoxicité et problèmes. Aliments Addit Contam. 2011; 28(3):282292. DOI.org/10.1080/19440049.2010.541288. https://doi.org/10.1080/19440049.2010.541288

7. Maregesi SM, Kauke B, Kagashe G, Kaali R, Médicaments oculaires traditionnels en Tanzanie:Produits, sensibilisation aux risques pour la santé et sécurité évaluation. Herb Med. 2016; 2(12):111.DOI: 10.21767 / 2472-0151.10008. https://doi.org/10.21767/2472-0151.100008

8. Talalay $P$, The importance of using scientific principles in the devepment of medicinal agents from plants. Acad Med. 2001; 76(3):238-247. DOI: 10.1097/00001888-200103000-00010. https://doi.org/10.1097/00001888-200103000-00010

9. Organization for Economic Co-operation and Development (OCDE) 423, OECD guidelines for testing chemical products, Acute oral toxicity - Acute toxicity class method. 2001, Lignes directrices pour les essais de produits chimiques (oecdilibrary.org). Accessed August 25, 2019.

10. Organization for Economic Co-operation and Development (OCDE) 407, OECD guidelines for testing chemical products, 28day repeated dose oral toxicity study in rodents. 2008 , 9789264070691-fr.pdf (oecd-ilibrary.org). Accessed August 25, 2019. 
11. Charles A, Jemima A, Kwesi B, Priscilla K, Aqueous leaf extract of Carica papaya (caricaceae) linn. Causes liver injury and reduced fertility in rats. IJPPS. 2016; 8(2):261-265.

12. Kassi Y., Toto K. N., Nanti G. G. C. G., Nene Bi S. A., Traoré F. (2018). Assessment of the effects of an aqueous trunk bark extract of Parkia biglobosa (mimosaceae) on blood sugar levels in rats. WJPPS. 2018; 7:174-186. DOI: 10.20959/wjpps20181012370 .

13. Nanti GGCG, Néné-Bi SA, Zahoui OS, Traoré F, Comparative study of Annona senegalensis (Annonaceae) and Hallea ledermannii (Rubiacaceae) effects on glycemia in rats. J Intercult Ethnopharmacol. 2018; 7(1):1-7. https://DOI.org/10.5455/jice.20170909091946. https://doi.org/10.5455/jice.20170909091946

14. Guirou C, Etude de la toxicité sub - chronique d'Argemone mexicana utilisée dans le traitement traditionnel du paludisme. Thèse de Pharmacie, FMPOS, Université de Bamako, 2008. p. 82.

15. Lullmann-Rauch R, Histologie. De Boeck Supérieur, Bruxelles, Belgique. 2008. P. 704.

16. Ozer J, Ratner M., Shaw M, Bailey W, Schomaker S, The current state of serum biomarkers of hepatotoxicity. Toxicology. 2008; 245:194-205. DOI: 10.1016/j.tox.2007.11.021. https://doi.org/10.1016/j.tox.2007.11.021
17. Wolf PL, Williams D, Tsudaka T, Acosta L, Methods and Techniques in Clinical Chemistry. John Wiley \& Sons, USA. 1972. p. 516.

18. Mukinda, Jame T, Syce, Jame A, Acute and chronic toxicity of the aqueous extract of Artemisia afra in rodents. J. Ethnopharmacol. 2007; 112(1):138-144. DOI: 10.1016/j.jep.2007.02.011. https://doi.org/10.1016/j.jep.2007.02.011

19. Goddard C and Warnes T, Raised liver enzymes in asymptomatic patients: investigation and outcome. Dig Dis. 1992; 10:218-226. DOI: $10.1159 / 000171360$ https://doi.org/10.1159/000171360

20. Palani S, Raja S, Praveen Kumar R, Soumya Jayakumar, Senthil Kumar B, Therapeutic, efficacy of Pimpinella tirupatiensis (Apiaceae) on acetaminophen induced nephrotoxicity and oxidative stress in male albino rats. Int.J. PharmTech Res. 2009 ; 1(3):925-934.

21. Bidie ADP, Adeoti FM, Yapo FA, Tiekpa JW, N'guessan JD, Djaman JA, Effet de l'extrait total aqueux de Chrysophyllum perpulchrum sur les paramètres hématologiques, biochimiques et la croissance pondérale des rats Wistars sains. Rev Ivoir. Sci. Technol. 2016; 28:333-348.

22. Omigie I, Agoreyo F, Effects of watermelon (Citrullus lanatus) seed on blood glucose and electrolyte parameters in diabetic Wistar rats. J. Appl. Sci. Environ. Manage. 2014; 18(2):231-233. DOI: $10.4314 /$ jasem.v18i2.12. https://doi.org/10.4314/jasem.v18i2.12 